\title{
Phenotypic diversity of Xanthomonas sp. mangiferaeindicae
}

\author{
O. Pruvost, A. Couteau, X. Perrier ${ }^{1}$ and J. Luisetti \\ CIRAD/INRA, Laboratoire de phytopathologie, Saint Pierre, Reunion Island, and ${ }^{1} C I R A D-F L H O R$, Service de \\ biométrie, Montpellier, France
}

6164/03/97: RECEIVED 25 March 1997, revised 30 April 1997 and accepted 2 May 1997

\begin{abstract}
O. Pruvost, A. couteau, X. Perrier And J. LUisetti. 1998. Carbohydrate utilization profiles by means of the API (Appareils et Procédés d'Identification) system and sensitivity to antibiotics and heavy metal salts of 68 Xanthomonas sp. mangiferaeindicae strains isolated in nine countries from mango (Mangifera indica L.) and other genera of the Anacardiaceae were examined to assess the variability of the taxon. The strains could be separated into 10 groups according to Ward clustering. Apigmented strains isolated from the pepper tree [syn. Brazilian pepper] (Schinus terebenthifolius Raddi) could not be clearly differentiated from most apigmented strains isolated from mango. Yellow-pigmented strains isolated from mango in Brazil and Reunion Island, apigmented strains isolated from mango in Brazil and from ambarella in the French West Indies, clustered in distinct groups. The results are consistent with those of other studies, based on isozyme analysis of esterase, phosphoglucomutase and superoxide dismutase, and $h r p$-RFLP analysis; they indicate the need for a comprehensive taxonomic evaluation of xanthomonads associated with Anacardiaceae.
\end{abstract}

\section{INTRODUCTION}

Xanthomonas sp. mangiferaeindicae (Vauterin et al. 1995) (syn. Xanthomonas campestris pv. mangiferaeindicae) is the causal agent of mango bacterial black spot (MBBS). It can infect all aerial organs and, although it does not induce a decline in trees, the bacterium can induce substantial crop losses and alteration of fruit quality (Pruvost and Manicom 1993). The incidence of MBBS is especially high in mango producing countries where high temperatures and rainfall occur at the same time of the year (Pruvost and Manicom 1993). MMBS occurs in many mango growing tropical and subtropical countries (see review by Pruvost et al. 1995).

Patel et al. (1948) reported that the host range includes other plant species of the family Anacardiaceae (i.e. cashew (Anacardium occidentale L.) and imra, also called emrah in the Malay peninsula (Spondias mangifera Willd $=S$. pinnata $(\mathrm{L}$. f.) Kurz), but bacterial strains from these host species are not currently available from international or laboratory culture collections. The pepper tree (syn. Brazilian pepper), Schinus terebenthifolius Raddi, another member of Anacardiaceae, was described as a new host species (Pruvost et al. 1992). Rott

Correspondence to: Dr Olivier Pruvost, CIRAD/INRA, Laboratoire de Phytopathologie, BP 180, 97455 Saint Pierre Cédex, Reunion Island, France (e-mail: pruvost@cirad.fr). and Frossard (1986) isolated a xanthomonad causing a severe dieback of ambarella (Spondias cytherea Sonnerat) in the French West Indies and noticed phenotypic similarities between the organism and Xanthomonas sp. mangiferaeindicae, although no lesions were observed in mango groves in the French West Indies. Pruvost and Luisetti (1989) obtained black lesions after inoculation of the ambarella strains on mango and cashew, and Koch postulates were verified. However, reciprocal inoculation with strains isolated from mango did not result in disease on ambarella (Pruvost and Luisetti 1989). According to Robbs et al. (1982), mombin (Spondias mombin L.) is another host species, and Pruvost and Luisetti (1989) successfully obtained lesions when mombin was inoculated with strains from ambarella, but not with strains from mango and the pepper tree.

Strains of Xanthomonas sp. mangiferaeindicae were originally described as apigmented (Dye et al. 1980), and this has been an important taxonomic character. Yellow-pigmented strains of Xanthomonas, inducing black angular lesions on mango, were described from Brazil (Robbs et al. 1978), from Reunion Island (Pruvost and Luisetti 1989), and from South Africa (Pruvost and Manicom 1993). Pruvost and Luisetti (1989) reported yellow-pigmented strains from Brazil and Reunion to be less pathogenic than apigmented isolates.

As the classification of Xanthomonas was long based on 
the pathovar concept, all strains isolated and pathogenic on mango, but with cultural characteristics different from the type strain (i.e. yellow-pigmented strains), or strains isolated from other plant species of the Anacardiaceae (i.e. ambarella, pepper tree) and pathogenic when inoculated on mango, were provisionally classified as pv. mangiferaeindicae (Robbs et al. 1978; Pruvost and Luisetti 1989; Pruvost et al. 1992), but Pruvost and Luisetti (1989) indicated that their taxonomic position should be evaluated carefully.

Little information is available on the physiology and metabolism of Xanthomonas sp. mangiferaeindicae. The comprehensive report by Manicom and Wallis (1984) included only apigmented strains isolated from mango (mostly in South Africa). Very recently, Somé and Samson (1996), when evaluating relationships among strains of Xanthomonas sp. mangiferaeindicae by isozyme analysis of esterase, phosphoglucomutase and superoxide dismutase, showed that the strains could be classified into eight groups. Group 1 included 12 apigmented strains isolated from mango in Australia, Comoro Islands, India, Reunion Island, South Africa and Taiwan, and five apigmented strains isolated from pepper trees in Reunion Island. Group 2 contained three apigmented strains isolated from mango in Brazil. Group 3 contained two apigmented strains isolated from ambarella in the French West Indies and group 4-8 comprised yellow-pigmented strains isolated from mango in Brazil and Reunion Island. Gagnevin et al. (1997), by RFLP analysis using a cluster of hrp genes from Xanthomonas oryzae pv. oryzae as a probe, obtained groups consistent with those of Somé and Samson (1996).

In this paper, an analysis is presented of the phenotypic diversity of strains of Xanthomonas sp. mangiferaeindicae isolated from several host genera belonging to the Anacardiaceae. The analysis is based on biochemical and physiological characteristics, utilization of a broad range of carbohydrates, organic acids and amino acids, and susceptibility to a range of antibiotics and heavy metal salts.

\section{MATERIALS AND METHODS}

\section{Bacterial strains}

Strains used in the study are listed in Table 1. All cultures were stored as lyophiles. They were checked for purity on LPGA (yeast extract $7 \mathrm{~g}$, bactopeptone $7 \mathrm{~g}$, glucose $7 \mathrm{~g}$, agar $15 \mathrm{~g}$, distilled water $1000 \mathrm{ml}, \mathrm{pH} 7 \cdot 2)$ plates. Cultures $(24 \mathrm{~h}-$ old) grown on Levure Peptone Glucose Agar (LPGA) slants at $28^{\circ} \mathrm{C}$ were used for all tests except where stated. Prior to characterization, all of the strains were confirmed to be pathogenic on mango leaves.

\section{Biochemical and physiological characteristics}

All tests were performed as described by Vernière et al. (1991) except for the following. Flagella stains were performed according to Rhodes (1958). The method of Sands (1990) was used to determine catalase activity. Acetoin production (Voges-Proskauer test) was tested using Clark and Lubs broth (Institut Pasteur, France, ref. 69166). Hydrolysis of Tween80 was performed on a medium containing yeast extract $5 \mathrm{~g}$, $\mathrm{NH}_{4} \mathrm{H}_{2} \mathrm{PO}_{4} 0.5 \mathrm{~g}, \mathrm{MgSO}_{4} .7 \mathrm{H}_{2} \mathrm{O} 0.2 \mathrm{~g}, \mathrm{NaCl} 5 \mathrm{~g}$, Tween-80 $1 \mathrm{ml}$, agar $15 \mathrm{~g}$, distilled water $1000 \mathrm{ml}(\mathrm{pH} \mathrm{7 \cdot 0)}$. The growth rate of strains was evaluated as the number of days necessary to obtain colonies $1 \mathrm{~mm}$ in diameter on LPGA plates $(4 \mathrm{~mm}$ thick) incubated at $28^{\circ} \mathrm{C}$. All tests were performed at least twice. Utilization of carbohydrates, organic acids and amino acids was done using API $50 \mathrm{CH}$, LRA $50 \mathrm{AO}$, and LRA 50 AA galleries (API System, La Balme-les Grottes, MontalieuVercieu, France) as recommended by the manufacturer. Galleries were incubated at $28^{\circ} \mathrm{C}$ and a minimum of two sets were inoculated per strain. Growth was observed in each well and compared to the control (well no. 0) after 3, 6 and $9 \mathrm{~d}$ under aseptic conditions. After $9 \mathrm{~d}$, samples were removed from all positive wells and streaked on LPGA plates to check for purity. Results were recorded as 1 (no growth) to 5 (very good growth).

\section{Susceptibility of $X$. sp. mangiferaeindicae to antibiotics and heavy metal salts}

The agar dilution susceptibility test (Barry 1991) was used to determine the minimal inhibitory concentration (MIC) of antimicrobic required to inhibit growth. The antibiotics included ampicillin, carbenicillin ( $\beta$ lactam antibiotics); streptomycin, kanamycin, gentamycin, kasugamycin (aminosides); chloramphenicol (chloramphenicol group); oxytetracycline (tetracyclines); erythromycin (macrolides); rifamycin SV (rifamycins); bacitracin (polypeptides); nalidixic acid, and flumequine (quinolones). Two heavy metal salts (copper sulphate and mercuric chloride) were also tested. Tests were performed on LPGA plates in which the concentration of antibiotics (and mercuric chloride) ranged from 1 to $128 \mu \mathrm{g}$ $\mathrm{ml}^{-1}$. Casitone Yeast Extract Glycerol Agar (CYE) medium (Zevenhuizen et al. 1979) was used to determine the sensitivity of $X$. sp. mangiferaeindicae to copper. Concentrations of metallic copper included in the medium ranged from 1 to $512 \mu \mathrm{g} \mathrm{ml}^{-1}$. Plates were seeded with a Steers' inoculator (Steers et al. 1959). Bacterial inocula were adjusted with sterile distilled water so that each droplet deposited on the agar medium contained approximately $10^{4}$ cells $\mathrm{ml}^{-1}$. Staphylococcus aureus (strain P209, obtained from Dr L. Gardan, INRA, France), the sensitivity of which to antibiotics and heavy metal salts is well known, was used as a standard. Plates without antibiotic were used as controls. Plates were incubated at $28{ }^{\circ} \mathrm{C}$ for $48 \mathrm{~h}$ prior to scoring except for ambarella strains, for which scoring was done after $4 \mathrm{~d}$. Data were transformed as $\log _{2}(\mathrm{MIC}) / 2$ in order to obtain a notation 
Table 1 Xanthomonas sp. mangiferaeindicae strains used in this study

\begin{tabular}{|c|c|c|c|c|c|c|}
\hline Strain & Origin & Host & Colony-type & $\begin{array}{l}\text { Year of } \\
\text { isolation }\end{array}$ & $\begin{array}{l}\text { Group } \\
\text { according to } \\
\text { Ward } \\
\text { clustering }\end{array}$ & Other numbers \\
\hline CFBP* 2922 & Australia & mango & apigmented & 1978 & 9 & ICMP† 6657 \\
\hline CFBP 2921 & Australia & mango & apigmented & 1978 & 9 & ICMP 6658 \\
\hline CFBP 2935 & Australia & mango & apigmented & 1978 & 9 & \\
\hline JF28-4 & Australia & mango & apigmented & 1978 & 9 & NCPPB $\$ 3124$ \\
\hline JF28-5 & Australia & mango & apigmented & 1978 & 9 & \\
\hline JF28-6 & Australia & mango & apigmented & 1978 & 9 & NCPPB 3125 \\
\hline JF28-7 & Australia & mango & apigmented & 1978 & 9 & \\
\hline JF28-8 & Australia & mango & apigmented & 1984 & 9 & \\
\hline JF28-9 & Australia & mango & apigmented & 1984 & 9 & \\
\hline JF28-10 & Australia & mango & apigmented & 1984 & 9 & \\
\hline JF28-11 & Australia & mango & apigmented & 1985 & 9 & \\
\hline JF28-12 & Australia & mango & apigmented & 1985 & 9 & \\
\hline CFBP 2912 & Brazil & mango & apigmented & 1978 & 4 & ICMP 4089 \\
\hline CFBP 2913 & Brazil & mango & apigmented & $?$ & 4 & ICMP 4088 \\
\hline CFBP 2914 & Brazil & mango & apigmented & $?$ & 4 & ICMP 4087 \\
\hline CFBP 2931 & Comoro Islands & mango & apigmented & 1986 & 8 & \\
\hline JF955 & Comoro Islands & mango & apigmented & 1986 & 8 & \\
\hline CFBP $1716 \S$ & India & mango & apigmented & 1957 & 9 & NCPPB 490 \\
\hline CFBP 2916 & India & mango & apigmented & 1970 & 8 & NCPPB 2387 \\
\hline CFBP 2936 & Mauritius Island & mango & apigmented & $?$ & 7 & \\
\hline JF29-2 & Mauritius Island & mango & apigmented & $?$ & 7 & \\
\hline JF29-3 & Mauritius Island & mango & apigmented & $?$ & 7 & \\
\hline CFBP 2930 & Mauritius Island & mango & apigmented & $?$ & 7 & \\
\hline JF29-5 & Mauritius Island & mango & apigmented & $?$ & 9 & \\
\hline JG98-1 & Mauritius Island & mango & apigmented & $?$ & 10 & \\
\hline JG98-2 & Mauritius Island & mango & apigmented & $?$ & 10 & \\
\hline JG98-3 & Mauritius Island & mango & apigmented & $?$ & 10 & \\
\hline CFBP 1717 & Reunion Island & mango & apigmented & 1975 & 9 & NCPPB 2885 \\
\hline G21-4 & Reunion Island & mango & apigmented & 1975 & 7 & \\
\hline L16-5 & Reunion Island & mango & apigmented & 1978 & 7 & \\
\hline $\mathrm{N} 236-4$ & Reunion Island & mango & apigmented & 1980 & 7 & \\
\hline JF30-3 & Reunion Island & mango & apigmented & 1979 & 7 & \\
\hline JF30-6 & Reunion Island & mango & apigmented & 1979 & 7 & \\
\hline A6-1 & Reunion Island & mango & apigmented & 1986 & 10 & \\
\hline A6-2 & Reunion Island & mango & apigmented & 1986 & 10 & \\
\hline A9 & Reunion Island & mango & apigmented & 1986 & 10 & \\
\hline A11-2 & Reunion Island & mango & apigmented & 1986 & 8 & \\
\hline A13 & Reunion Island & mango & apigmented & 1986 & 10 & \\
\hline $\mathrm{A} 23$ & Reunion Island & mango & apigmented & 1986 & 9 & \\
\hline A24-1 & Reunion Island & mango & apigmented & 1986 & 8 & \\
\hline A26-1 & Reunion Island & mango & apigmented & 1986 & 8 & \\
\hline $\mathrm{B} 17$ & Reunion Island & mango & apigmented & 1987 & 10 & \\
\hline CFBP 2915 & South Africa & mango & apigmented & 1971 & 9 & NCPPB 2438 \\
\hline JF950 & South Africa & mango & apigmented & 1986 & 8 & \\
\hline JF951 & South Africa & mango & apigmented & 1986 & 8 & \\
\hline JF952 & South Africa & mango & apigmented & 1986 & 8 & \\
\hline JF953 & South Africa & mango & apigmented & 1986 & 8 & \\
\hline CFBP 2926 & South Africa & mango & apigmented & $?$ & 8 & \\
\hline JG725 & South Africa & mango & apigmented & $?$ & 8 & \\
\hline JG726 & South Africa & mango & apigmented & ? & 8 & \\
\hline JG727 & South Africa & mango & apigmented & $?$ & 8 & \\
\hline
\end{tabular}


Table 1 Continued

\begin{tabular}{|c|c|c|c|c|c|c|}
\hline Strain & Origin & Host & Colony-type & $\begin{array}{l}\text { Year of } \\
\text { isolation }\end{array}$ & $\begin{array}{l}\text { Group } \\
\text { according to } \\
\text { Ward } \\
\text { clustering }\end{array}$ & Other numbers \\
\hline CFBP 2934 & South Africa & mango & apigmented & ? & 8 & \\
\hline JG729 & South Africa & mango & apigmented & $?$ & 8 & \\
\hline JG730 & South Africa & mango & apigmented & $?$ & 8 & \\
\hline JG731 & South Africa & mango & apigmented & $?$ & 10 & \\
\hline JG732 & South Africa & mango & apigmented & $?$ & 8 & \\
\hline A 22 & Reunion Island & pepper tree & apigmented & 1986 & 10 & \\
\hline CFBP 2938 & Reunion Island & pepper tree & apigmented & 1986 & 10 & \\
\hline CFBP 2928 & Reunion Island & pepper tree & apigmented & 1987 & 10 & \\
\hline CFBP 2940 & Reunion Island & pepper tree & apigmented & 1987 & 10 & \\
\hline CFBP 2939 & Reunion Island & pepper tree & apigmented & 1987 & 10 & \\
\hline CFBP 2547 & French West Indies & ambarella & apigmented & 1985 & 3 & \\
\hline CFBP 2623 & French West Indies & ambarella & apigmented & 1985 & 3 & \\
\hline CFBP 2923 & Brazil & mango & yellow-pigmented & 1967 & 5 & $\begin{array}{l}\text { NCPPB } 3078 \\
\text { ICMP } 4090\end{array}$ \\
\hline CFBP 2924 & Brazil & mango & yellow-pigmented & 1974 & 6 & NCPPB 3110 \\
\hline CFBP 2920 & Reunion Island & mango & yellow-pigmented & 1986 & 1 & \\
\hline CFBP 2919 & Reunion Island & mango & yellow-pigmented & 1986 & 2 & \\
\hline CFBP 2918 & Reunion Island & mango & yellow-pigmented & 1986 & 2 & \\
\hline
\end{tabular}

* Collection Française de Bactéries Phytopathogènes, Angers (France).

$\uparrow$ International Collection of Micro-organisms from Plants, Auckland (New Zealand).

† National Collection of Plant Pathogenic Bacteria, Harpenden (UK).

§ Type strain.

scale comparable to that of the biochemical and physiological data.

\section{Statistical analysis}

API data supplemented with data from biochemical and physiological tests (Table 2) for which strains exhibited variability, and data from antibiotic susceptibility testing, were used for hierarchical cluster analysis (HCA). A computer program in FORTRAN (Jambu 1978) and now available for personal computers $\left(\right.$ Statlab $^{\mathrm{TM}} 2.0$ - SLP, Monterey, CA, USA) was used. Clustering was by the method of Ward (1963) on the Euclidean distance between the strains. The optimal truncating level in the dendrogram was thus determined by statistically evaluating the variance within each cluster vs variance between clusters. Contribution (ctr) and correlation (cor) values are given in each analysis by the software as an aid to interpretation. Contribution allows the determination of the importance of each variable on the variance within each group, whereas cor indicates the variables which define each group.

\section{RESULTS}

The results of the physiological and biochemical tests are presented in Table 2. Six characters allow a clear-cut separation of four groups. The results reveal the existence of variability within apigmented strains isolated from mango; strains isolated from Brazil can be distinguished from other strains on the basis of their ability to hydrolyse Tween-80 and lack of pectolytic activity on the medium of Hildebrand (1971). Apigmented strains isolated from pepper tree were indistinguishable from most apigmented strains isolated from mango (Table 2).

All the strains showed the same utilization pattern for 123 of the 147 carbon sources (84\%) tested. All utilized glycerol, galactose, D-glucose, D-fructose, D-mannose, $N$-acetylglucosamine, aesculin, cellobiose, saccharose, trehalose, D-lyxose, succinic acid, fumaric acid, L-malic acid and pyruvic acid. Substrates not utilized were erythritol, Darabinose, L-arabinose, ribose, L-xylose, adonitol, $\beta$ methylxyloside, L-sorbose, rhamnose, dulcitol, inositol, sorbitol, $\alpha$-methyl D-mannoside, $\alpha$-methyl D-glucoside, arbutin, salicin, inulin, D-melezitose, D-raffinose, xylitol, D-turanose, 
Table 2 Biochemical and physiological characteristics of Xanthomonas sp. mangiferaeindicae

\begin{tabular}{|c|c|c|c|c|c|}
\hline Character studied & $\begin{array}{l}\text { Apigmented } \\
\text { strains } \\
\text { isolated } \\
\text { from mango } \\
\text { in Brazil } \\
n=3\end{array}$ & $\begin{array}{l}\text { Apigmented } \\
\text { strains } \\
\text { isolated from } \\
\text { mango in } \\
\text { other } \\
\text { countries } \\
n=53\end{array}$ & $\begin{array}{l}\text { Apigmented } \\
\text { strains } \\
\text { isolated } \\
\text { from pepper } \\
\text { tree } \\
n=5\end{array}$ & $\begin{array}{l}\text { Apigmented } \\
\text { strains } \\
\text { isolated } \\
\text { from } \\
\text { ambarella } \\
n=2\end{array}$ & $\begin{array}{l}\text { Yellow- } \\
\text { pigmented } \\
\text { strains } \\
\text { isolated } \\
\text { from mango } \\
n=5\end{array}$ \\
\hline Gram & - & - & - & - & - \\
\hline Motility & + & + & + & + & + \\
\hline Presence of flagella & 1-polar & 1-polar & 1-polar & 1-polar & 1-polar \\
\hline Color of colonies & white & white & white & white & yellow \\
\hline Speed of growth & 2 & 2 & 2 & 5 & 2 \\
\hline $\mathrm{O} / \mathrm{F}$ glucose metabolism & oxidative & oxidative & oxidative & oxidative & oxidative \\
\hline Oxidase & - & - & - & - & - \\
\hline Catalase & + & + & + & + & + \\
\hline Nitrate reductase & - & - & - & - & - \\
\hline Urease & - & - & - & - & - \\
\hline Indole production & - & - & - & - & - \\
\hline Acetoin production & - & - & - & - & - \\
\hline Arginine dihydrolase & - & - & - & - & - \\
\hline Fluorescent pigments & - & - & - & - & - \\
\hline Starch hydrolysis & + & + & + & + & + \\
\hline Gelatin hydrolysis & + & + & + & + & + \\
\hline Esculin hydrolysis & + & + & + & + & + \\
\hline Milk proteolysis & + & + & + & + & + \\
\hline Cellulose hydrolysis & + & + & + & + & + \\
\hline Tween-80 hydrolysis & + & - & - & - & + \\
\hline $\mathrm{H}_{2} \mathrm{~S}$ from cysteine & + & + & + & + & + \\
\hline Pectinolytic activity (Prunier and Kaiser 1964) & - & - & - & - & + \\
\hline Pectinolytic activity pH 5·0 (Hildebrand 1971) & - & - & - & - & - \\
\hline Pectinolytic activity pH 7.0 (Hildebrand 1971) & - & $(+)$ & + & - & + \\
\hline Pectinolytic activity pH 8.5 (Hildebrand 1971) & - & $(+)$ & + & - & + \\
\hline Tolerance to $\mathrm{NaCl}$ & $3 \%$ & $3 \%$ & $3 \%$ & $<1 \%$ & $3 \%$ \\
\hline HR on tomato & + & + & + & + & + \\
\hline
\end{tabular}

Characters are italicized when variation occurred among strains.

+ , positive reaction $(100 \%$ of strains); $(+)$, positive reaction for more than $90 \%$ of strains; - , negative reaction.

D-tagatose, D-fucose, D-arabitol, L-arabitol, gluconic acid, 2cetogluconic acid, 5-cetogluconic acid, acetic acid, propionic acid, butyric acid, isobutyric acid, $n$-valeric acid, isovaleric acid, $n$-caproic acid, heptanoic acid, caprylic acid, pelargonic acid, capric acid, oxalic acid, malonic acid, maleic acid, glutaric acid, adipic acid, pimelic acid, suberic acid, azelic acid, sebacic acid, glycolic acid, D-L-3-hydroxybutyric acid, Dmalic acid, L-tartaric acid, mesotartaric acid, levulinic acid, citraconic acid, itaconic acid, mesaconic acid, phenylacetic acid, benzoic acid, $o$-hydroxybenzoic acid, $m$-hydroxybenzoic acid, D-mandelic acid, L-mandelic acid, phthalic acid, isophthalic acid, terophthalic acid, glycine, L-leucine, L-isoleucine,
L-norleucine, L-valine, D-L-norvaline, D-L-2-aminobutyric acid, L-serine, L-threonine, L-cysteine, L-methionine, Lphenylalanine, L-tyrosine, D-tryptophan, L-tryptophan, trigonelline, L-glutamic acid, L-ornithine, L-lysine, L-citrulline, L-arginine, D-L-kynurenine, betaine, creatine, $\beta$ alanine, D-L-3-aminobutyric acid, D-L-4-aminobutyric acid, D-L-5 aminovaleric acid, D-L-2-aminobenzoic acid, D-L-3aminobenzoic acid, D-L-4-aminobenzoic acid, urea, acetamide, sarcosine, ethylamine, butylamine, amylamine, ethanolamine, benzylamine, diaminobutane, spermine, histamine, tryptamine and glucosamine.

Variations were recorded among strains for the following 
substrates: D-xylose, mannitol, amygdalin, maltose, lactose, melibiose, starch, glycogen, $\beta$-gentiobiose, L-fucose, D-Llactic acid, D-L-glyceric acid, D-tartaric acid, 2-cetoglutaric acid, aconitic acid, citric acid, p-hydroxybenzoic acid, D$\alpha$-alanine, L- $\alpha$-alanine, L-histidine, L-aspartic acid and Lproline.

Minimal inhibitory concentrations are presented in Table 3. From the correlation matrix among variables (data not shown), four variables (i.e. streptomycin, kanamycin, gentamycin and oxytetracycline) were strongly correlated. Since three out of the four were from the same antibiotic family, data for streptomycin and gentamycin were deleted from the data table prior to HCA.

The phenotypic relationships among strains are presented in Fig. 1. Strains clustered in 10 groups according to the statistical analysis determining the optimal truncating level. The majority of the strains clustered in four groups (groups 7-10, Fig. 1). All these strains produced apigmented colonies and were isolated from either the pepper tree or from mango in any country except Brazil. All these groups included strains from several countries, and strains from one country often clustered in different groups. Strains isolated in Australia constituted a noticeable exception, although they were isolated in several areas over a period of eight years. Strains isolated in Reunion Island from the pepper tree all clustered in group 10 together with strains isolated from mango in Reunion Island, Mauritius Island and South Africa.

Group 3 included strains isolated from ambarella in the French West Indies. Strains isolated from mango in Brazil were in group 4. The five yellow-pigmented strains isolated from mango in various areas of the world were distributed in four different groups (groups 1, 2, 5 and 6).

\section{DISCUSSION}

In the 1970s, a classification of xanthomonads according to the host species or the host botanical family from which they were isolated was proposed for the convenience of plant pathologists. This led to the concept of pathovars (Dye et al. 1980) and thus, most xanthomonads, whose identification by classical physiological tests (Dye 1962) is frequently impossible, were classified on the basis of a single characteristic (i.e. pathogenicity) into pathovars of a single species, X. campestris. Several studies have shown that the pathovar system has important deficiencies (Gabriel et al. 1989; Hildebrand et al. 1990; Swings et al. 1990; Stall and Civerolo 1991; Stall et al. 1994), and Vauterin et al. (1990) made a strong case for the re-evaluation of the classification of Xanthomonas on the basis

Table 3 Minimal inhibitory concentrations (MICs) of Xanthomonas sp. mangiferaeindicae towards a panel of antibiotics and heavy metal salts

\begin{tabular}{|c|c|c|c|c|c|}
\hline Inhibitor & $\begin{array}{l}\text { Apigmented } \\
\text { strains } \\
\text { isolated } \\
\text { from mango } \\
\text { in Brazil } \\
n=3\end{array}$ & $\begin{array}{l}\text { Apigmented } \\
\text { strains } \\
\text { isolated from } \\
\text { mango in } \\
\text { other } \\
\text { countries } \\
n=53\end{array}$ & $\begin{array}{l}\text { Apigmented } \\
\text { strains } \\
\text { isolated } \\
\text { from pepper } \\
\text { tree } \\
n=5\end{array}$ & $\begin{array}{l}\text { Apigmented } \\
\text { strains } \\
\text { isolated } \\
\text { from } \\
\text { ambarella } \\
n=2\end{array}$ & $\begin{array}{l}\text { Yellow- } \\
\text { pigmented } \\
\text { strains } \\
\text { isolated } \\
\text { from mango } \\
n=5\end{array}$ \\
\hline Ampicillin & $512^{*}$ & $16-128$ & $32-128$ & 64 & $2-128$ \\
\hline Carbenicillin & 8-16 & $8-64$ & $16-64$ & 16 & $2-32$ \\
\hline Streptomycin & $1-2$ & 1 & 1 & 1 & $1-4$ \\
\hline Kanamycin & 1 & 1 & 1 & 1 & $1-16$ \\
\hline Gentamycin & 1 & 1 & 1 & 1 & 1-2 \\
\hline Kasugamycin & $64-128$ & $32-128$ & $32-64$ & 32 & $128-256$ \\
\hline Chloramphenicol & 8 & $4-16$ & 8 & 1 & $8-16$ \\
\hline Erythromycin & $2-4$ & $1-2$ & 2 & 1 & 2-8 \\
\hline Rifamycin & 16 & $8-16$ & $8-16$ & 8 & $16-32$ \\
\hline Bacitracin & 128 & $32-128$ & $64-128$ & 16 & $32-128$ \\
\hline Nalidixic acid & 8-16 & 8-32 & 16 & 4 & $8-16$ \\
\hline Flumequine & 2 & $1-2$ & $1-2$ & 1 & $1-8$ \\
\hline $\mathrm{HgCl}_{2}$ & 8 & $2-8$ & 4-8 & 16 & $8-16$ \\
\hline $\mathrm{CuSO}_{4}$ & 16 & $8-16$ & 16 & 8 & 16 \\
\hline
\end{tabular}

* Data are given in $\mu \mathrm{g} \mathrm{ml}^{-1}$. 


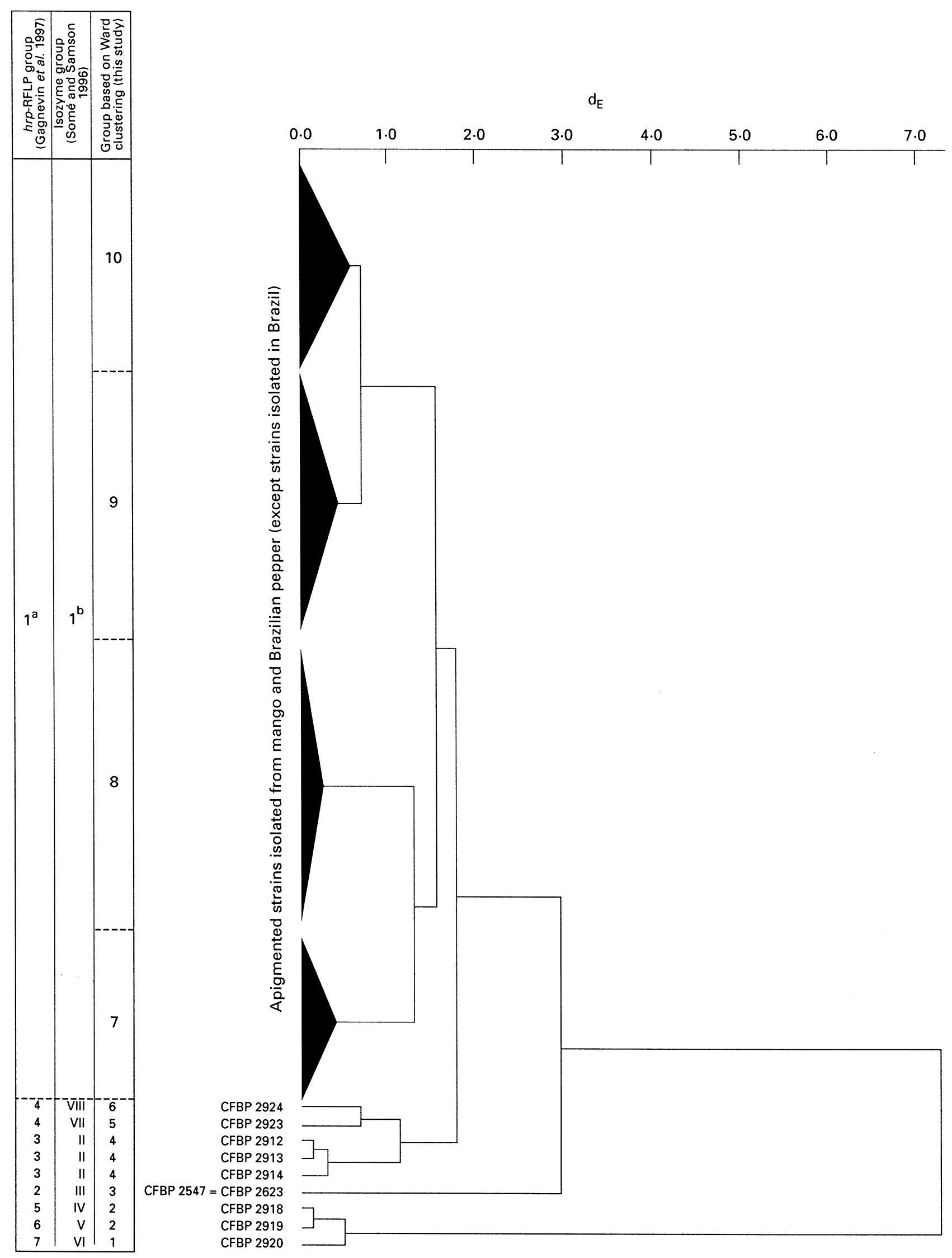

Fig. 1 Dendogram of phenotypic features of strains of Xanthomonas sp. mangiferaeindicae based on their metabolic activities and their susceptibility to antibiotics and heavy metal salts. ${ }^{\mathrm{a}} 127$ strains were analysed. ${ }^{\mathrm{b}} 17$ strains were analysed. 
of phenotypic, chemotaxonomic and genotypic features. Studies using this polyphasic approach improved the taxonomy of Xanthomonas (see review by Vauterin et al. 1993) and as a consequence, a reclassification of Xanthomonas was proposed (Vauterin et al. 1995). However, the group previously named $X . c$. pv. mangiferaeindicae was not included in this new classification, and the authors proposed a temporary designation (Xanthomonas sp. mangiferaeindicae).

In a numerical analysis of 295 phenotypic features (Van Den Mooter and Swings 1990), the neopathotype strain of $X$. sp. mangiferaeindicae, the only strain included, clustered in phenon 9 . The majority of strains in phenon 9 hydrolysed Tween-80. However, of the mangiferaeindicae strains studied here, only the yellow-pigmented strains and three apigmented strains from Brazil hydrolysed Tween-80. All negative strains were checked for Tween- 80 hydrolysis on a different medium (Sierra 1957) to the one used in this study. Nearly half of them were negative. Some gave very weak positive reactions after $21 \mathrm{~d}$ when colonies were cultured on very thick agar plates but frequently, these results could not be reproduced.

In an analysis of DNA relatedness among xanthomonads (Palleroni et al. 1993), only one strain of X. sp. mangiferaeindicae, the precise origin and characteristics of which were not given, grouped with strains belonging to DNADNA homology group 1 which included numerous other former $X$. campestris pathovars. The closest taxon was $X$. axonopodis pv. phaseoli.

Other studies conducted to evaluate relationships between xanthomonads, e.g. restriction fragment length polymorphism of genomic DNA (Lazo et al. 1987), gas chromatographic analysis of fatty acid methyl esters (Yang et al. 1993), restriction patterns of rDNAs (Berthier et al. 1993), electrophoresis of outer membrane proteins and lipopolysaccharides (Ojanen et al. 1993), included only one or very few $X$. sp. mangiferaeindicae strains isolated from mango. Consequently, as was to be expected, these studies did not provide useful information on any variability in the mangiferaeindicae group.

In the present study, based on phenotypic characteristics, 68 strains provisionally classified as $X$. sp. mangiferaeindicae were distributed in 10 groups according to their metabolic profiles and their sensitivity to antibiotics and heavy metal salts (Fig. 1). Separate cluster analyses on data derived (i) from biochemical and API tests and (ii) from susceptibility to antibiotics and heavy metals (data not shown) indicated that the grouping of strains based on the different data sets were not fully consistent one to the other. It is possible that the groups of genes involved have evolved differently over time. In the case of $\beta$ lactam antibiotics, a single point mutation in a $\beta$ lactamase encoding gene can change the substrate specificity of the enzyme (Davies 1994). Other resistance mechanisms to $\beta$ lactam antibiotics have been described, but they are related to the intensive use of this antibiotic family for animal and human bacterial pathogens (Davies 1994). Therefore, it is unlikely that they would be involved in the resistance of plant pathogens, as $\beta$ lactam antibiotics are not used in agriculture. Gene transfer associated with mobile DNA elements carrying antibiotic resistance genes (i.e. R plasmids, integrons etc.) is common in the microbial kingdom (Davies 1994) and may account for the differences observed in the present study. Gardan and Manceau (1987) reported that $\mathrm{R}$ plasmids can be transferred by conjugation on hazelnut phylloplane (i) between strains of Xanthomonas arboricola pv. corylina and (ii) between Pantoea dispersa (syn. Erminia herbicola) and $X$. a. pv. corylina, and vice versa.

The classification based on the present data was consistent with those obtained by isozyme analysis (Somé and Samson 1996) and by RFLP analysis using a cluster of $h r p$ genes from Xanthomonas oryzae pv. oryzae as a probe (hrp-RFLP) (Gagnevin et al. 1997) (Fig. 1).

In this study, most apigmented strains isolated from mango (except group 4 strains from Brazil) and all strains isolated from the pepper tree were separated into four groups (group 7-10) (Fig. 1). The lack of a meaningful relationship between the group composition and the geographical origin of the strains may indicate that (i) strains of $X$. sp. mangiferaeindicae from Africa, Asia and Oceania have not evolved differently over time and (ii), long distance movement of $X$. sp. mangiferaeindicae may be associated mainly with exchanges of contaminated propagating plant material.

Interestingly, all strains isolated in Reunion Island belonging to group 7 were isolated between 1974 and 1980, whereas other strains were most often isolated in 1986 or later. The isolation date of group 7 strains from other countries is not available. This raises the possibility that this observation could be related to an evolution of $X$. sp. mangiferaeindicae over time, or to laboratory cultivation. Schortichini and Rossi (1995) reported that subculturing sometimes influenced carbohydrate utilization profiles obtained with the API system. This was the case for one strain (out of four included in the study) of $X . c$. pv. campestris.

It was not possible to obtain a clear-cut differentiation of strains from the pepper tree by means of phenotypic features under our experimental conditions. This is consistent with data previously published (Pruvost et al. 1992) and with the results of isozyme analysis (Somé and Samson 1996). Reciprocal artificial inoculations of isolates originating from both host genera showed that all strains can produce black lesions on mango and the pepper tree (Pruvost et al. 1992). However, a very recent study of the genetic relationships of these strains by RFLP analysis using an avirulence gene from $X . o$. pv. oryzae and a highly repeated DNA sequence from $X$. sp. mangiferaeindicae as probes (Gagnevin et al. 1997), showed that strains from the pepper tree have unique RFLP patterns. Such patterns were never found in more than 100 
strains isolated from mango, even from mango in close proximity to diseased pepper trees, thus questioning the potential role of the pepper tree as an inoculum reservoir for mango bacterial black spot under natural conditions. This is presently under investigation.

The results presented here show that (i) apigmented strains isolated from mango in Brazil, (ii) apigmented strains isolated from ambarella in the French West Indies and (iii) yellowpigmented strains isolated from mango, are clearly different from 'typical' apigmented strains isolated from mango and pepper tree (i.e. strains classified in groups $7-10$ in the present study). This is fully consistent with data based on isozyme analysis (Somé and Samson 1996) and RFLP analysis (Gagnevin et al. 1997) [Fig. 1].

It is possible that apigmented strains isolated from mango in Brazil are part of a population which have evolved independently of other apigmented strains which probably originate from Asia. Further work is needed to evaluate the significance of these strains. A study of a larger strain collection from Brazil would be of interest to evaluate how clonal this population is and to evaluate quantitatively the pathogenicity of these strains compared with those of 'typical' apigmented strains.

Yellow-pigmented strains isolated from mango were clearly distinct from 'typical' strains. Our data suggest a high heterogeneity among these strains (they constitute four different Ward groups). This is in total concordance with results obtained by Somé and Samson (1996) by isozyme analysis and by Gagnevin et al. (1997) by hrp-RFLP analysis.

All these data suggest the possibility that (i) apigmented strains isolated from mango in Brazil, (ii) apigmented strains isolated from ambarella in the French West Indies and (iii) yellow-pigmented strains isolated from mango and provisionally classified as $X$. sp. mangiferaeindicae based on their pathogenicity to mango, constitute taxa different from the one(s) containing most apigmented strains from mango and the pepper tree. More data are needed to address this hypothesis using a polyphasic approach, as recommended by Vauterin et al. (1990).

\section{ACKNOWLEDGEMENTS}

This work was supported in part by a grant from the Ministère de la Recherche et de l'Enseignement Supérieur (France).

The authors would like to thank Drs M. Moffett, P. Fahy, B. Manicom, J. Moll and S. Beni Mahdu for providing bacterial cultures. Thanks are also due to Drs J. Leach, E. Civerolo, J. Hartung, L. Claflin and P. Rott for reviewing the manuscript.

\section{REFERENCES}

Barry, A.L. (1991) Procedures and theoretical considerations for testing antimicrobial agents in agar media. In Antibiotics in Laboratory Medicine ed. Lorian, V. 3rd edn. pp. 1-16. Baltimore: Williams and Wilkins.

Berthier, Y., Verdier, V., Guesdon, J.L. et al. (1993) Characterization of Xanthomonas campestris pathovars by rRNA gene restriction patterns. Applied and Environmental Microbiology 59, 851-859.

Davies, J. (1994) Inactivation of antibiotics and the dissemination of resistance genes. Science 264, 375-382.

Dye, D.W. (1962) The inadequacy of the usual determinative tests for the identification of Xanthomonas spp. New Zealand Fournal of Science 5, 393-416.

Dye, D.W., Bradbury, J.F., Goto, M., Hayward, A.C., Lelliott, R.A. and Schroth, M.N. (1980) International standards for naming pathovars of phytopathogenic bacteria and a list of pathovar names and pathotype strains. Reviem of Plant Pathology 59, 153-168.

Gabriel, D.W., Kingsley, M.T., Hunter, J.E. and Gottwald, T.R. (1989) Reinstatement of Xanthomonas citri (ex Hasse) and X. phaseoli (ex Smith) to species and reclassification of all $X$. campestris pv. citri strains. International Journal of Systematic Bacteriology 39, 14-22.

Gagnevin, L., Leach, J.E. and Pruvost, O. (1997) Genomic variability of Xanthomonas sp. mangiferaeindicae, agent of mango bacterial black spot. Applied and Environmental Microbiology 63, 246253.

Gardan, L. and Manceau, C. (1987) Transfer of RP4 on leaf surface of hazelnut. Proceedings of the $6^{\text {th }}$ International Conference on Plant Pathogenic Bacteria. pp. 756-762. Beltsville, MD: Martinus Nijhoff.

Hildebrand, D.C. (1971) Pectate and pectin gels for differentiation of Pseudomonas sp. and other bacterial plant pathogens. Phytopathology 61, 1430-1436.

Hildebrand, D.C., Palleroni, N.J. and Schroth, M.N. (1990) Deoxyribonucleic acid relatedness of 24 xanthomonad strains representing 23 Xanthomonas campestris pathovars and Xanthomonas fragariae. Journal of Applied Bacteriology 68, 263-269.

Jambu, M. (1978) Classification Automatique pour l'Analyse des Données. 1. Méthodes et Algorithmes ed. Jambu, M. p. 301. Paris: Dunod.

Lazo, G.R., Roffey, R. and Gabriel, D.W. (1987) Pathovars of Xanthomonas campestris are distinguishable by Restriction-Fragment-Length-Analysis. International Fournal of Systematic Bacteriology 37, 214-221.

Manicom, B.Q. and Wallis, F.M. (1984) Further characterization of Xanthomonas campestris pv. mangiferaeindicae. International Fournal of Systematic Bacteriology 34, 77-79.

Ojanen, T., Helander, I.M., Haahtela, K., Korhonen, T.K. and Laakso, T. (1993) Outer membrane proteins and lipopolysaccharides in pathovars of Xanthomonas campestris. Applied and Environmental Microbiology 59, 4143-4151.

Palleroni, N.J., Hildebrand, D.C., Schroth, M.N. and Hendson, M. (1993) Deoxyribonucleic acid relatedness of 21 strains of Xanthomonas species and pathovars. Fournal of Applied Bacteriology 75, 441-446.

Patel, M.K., Kulkarni, Y.S. and Moniz, L. (1948) Pseudomonas mangiferae-indicae, pathogenic on mango. Indian Phytopathology $1,147-152$.

Prunier, J.P. and Kaiser, P. (1964) Etude de l'activité pectinolytique 
chez des bactéries phytopathogènes et saprophytes des plantes. I. Recherche des enzymes pectinolytiques. Annales des Épiphyties $15,205-219$.

Pruvost, O., Couteau, A. and Luisetti, J. (1992) Pepper tree (Schinus terebenthifolius Radii), a new host plant for Xanthomonas campestris pv. mangiferaeindicae. Fournal of Phytopathology 135, 289-298.

Pruvost, O., Couteau, A., Luisetti, J. and Vernière, C. (1995) Biologie et épidémiologie de l'agent de la maladie des taches noires de la mangue. Fruits 50, 182-188.

Pruvost, O. and Luisetti, J. (1989) Strains of Xanthomonas campestris isolated from Ambarella (Spondias cytherea Sonn. ) in the French West Indies are probably a new pathogenic form of Xanthomonas campestris pv. mangiferaeindicae. Fruits 44, 539-542.

Pruvost, O. and Manicom, B.Q. (1993) Xanthomonas campestris pv. mangiferaeindicae, cause of bacterial black spot of mangoes. In Xanthomonas ed. Swings, J.G. and Civerolo, E.L. pp. 91-95. London: Chapman and Hall.

Rhodes, M.E. (1958) The cytology of Pseudomonas sp., as revealed by a silver platine method. Fournal of General Microbiology 18, 639-648.

Robbs, C.F., Da Ponte, J.J. and Da Gloria Sales, M. (1978) Nota sobre Xanthomonas mangiferaeindicae no nordeste do Brasil. Fitopatologia Brasileira 3, 215-217.

Robbs, C.F., Neto, J.R., Ribeiro, R.L. and Kimura, O. (1982) Annotated list of bacterial plant pathogens in Brazil, Proceedings of the $5^{\text {th }}$ International Conference on Plant Pathogenic Bacteria ed. Lozano, J. C. and Gwin, P. pp. 601-613. Cali: CIAT.

Rott, P. and Frossard, P. (1986) Un chancre bactérien du Prunier de Cythère (Spondias cytherea, Sonn.) en Martinique. Fruits 41, 605-613

Sands, D.C. (1990) Physiological criteria. Determinative tests. In Methods in Phytobacteriology ed. Klement, Z., Rudolph, K. and Sands, D.C. pp. 133-143. Budapest: Akademiai Kiado.

Scortichini, M. and Rossi, M.P. (1995) Influence of subculturing some phytopathogenic bacteria on their carbohydrate utilizing profile. Letters in Applied Microbiology 21, 237-241.

Sierra, G. (1957) A simple method for the detection of lipolytic activity of micro-organisms and some observations on the influence of the contact between cells and fatty substrates. Antonie Van Leeumenhoek 23, 15-22.

Somé, A. and Samson, R. (1996) Isoenzyme diversity in Xanthomonas campestris pv. mangiferaeindicae. Plant Pathology 45, $426-431$
Stall, R.E., Beaulieu, C., Egel, D. et al. (1994) Two genetically diverse groups of strains are included in Xanthomonas campestris pv. vesicatoria. International Journal of Systematic Bacteriology 44, $47-53$.

Stall, R.E. and Civerolo, E.L. (1991) Research relating to the recent outbreak of citrus canker in Florida. Annual Reviem of Phytopathology 29, 399-420.

Steers, E., Foltz, B.L. and Graves, B.S. (1959) An inocula replicating apparatus for routine testing of bacterial susceptibility to antibiotics. Antibiotics and Chemotherapy 9, 307-310.

Swings, J., Van Den Mooter, M., Vauterin, L. et al. (1990) Reclassification of the causal agents of bacterial blight (Xanthomonas campestris pv. oryzae) and bacterial leaf streak (Xanthomonas campestris pv. oryzicola) as pathovars of Xanthomonas oryzae (ex Ishiyama 1922) sp. nov., nom. rev. International Fournal of Systematic Bacteriology 40, 309-311.

Van Den Mooter, M. and Swings, J. (1990) Numerical analysis of 295 phenotypic features of 266 Xanthomonas strains and related strains and an improved taxonomy of the genus. International Fournal of Systematic Bacteriology 40, 348-369.

Vauterin, L., Hoste, B., Kersters, K. and Swings, J. (1995) Reclassification of Xanthomonas. International fournal of Systematic Bacteriology 45, 472-489.

Vauterin, L., Hoste, B., Yang, P., Alvarez, A., Kersters, K. and Swings, J. (1993) Taxonomy of the genus Xanthomonas. In Xanthomonas ed. Swings, J.G. and Civerolo, E.L. pp. 157-192. London: Chapman and Hall.

Vauterin, L., Swings, J., Gillis, M. et al. (1990) Towards an improved taxonomy of Xanthomonas. International Fournal of Systematic Bacteriology 40, 312-316.

Vernière, C., Devaux, M., Pruvost, O., Couteau, A. and Luisetti, J. (1991) Studies on the biochemical and physiological variations among strains of Xanthomonas campestris pv. citri, the causal agent of citrus bacterial canker disease. Fruits 46, 162-170.

Ward, J.H. (1963) Hierarchical grouping to optimize an objective function. American Statistical Association fournal 58, 236-244.

Yang, P., Vauterin, L., Vancanneyt, M., Swings, J. and Kersters, K. (1993) Application of fatty acid methyl esters for the taxonomic analysis of the genus Xanthomonas. Systematic and Applied Microbiology 16, 47-71.

Zevenhuizen, L.P.T.M., Dolfing, J., Eshuis, E.J. and ScholtenKoerselman, I. J. (1979) Inhibitory effects of copper on bacteria related to the free ion concentration. Microbial Ecology 5, 139164. 